\title{
Sylvia Plath, the Well-Bred Malaise, and its Confession in 'Daddy'
}

\author{
S. Z. Abbas \\ Associate Professor, Department of English Language and Literature, Prince Sattam Bin \\ Abdulaziz University, Wadi Al Dawasir, Kingdom of Saudi Arabia. \\ Email: s.abbas@psau.edu.sa
}

\begin{abstract}
Writing confessional lyrics, which are highly subjective and intensely personal, needs an extraordinarily sensitive mind that tends to break down while systematically probing that narrow and violent area of experience between the viable and the impossible, transmuted into poetry. This was Plath's "way of ordering and reordering the chaos of experience." Plath's neurosis led her to commit suicide at the age of thirty-one, and since then critics have not been able to study her poetry away from her tempestuous life. The article studies a probable link between creativity and mental illness that Dean Keath Simonton calls 'Mad-Genius Paradox,' thereby floating a hypothesis that either it was Sylvia Plath's writing that made her depressed and eventually influenced her decision to commit suicide or it was her depression and psychopathology that influenced her poetry, which resulted in her best collection Ariel. The article also studies her poem 'Daddy,' which is included in Ariel, hailed as "the Guernica of Modern Poetry," more of a dying statement in a "controlled hallucination," and concludes that Plath's confessional mode, her psychosis, and her creative genius finds a zenith in the poem. 'Daddy' is a Freudian exercise where Plath finds her muse in her father while rejecting him and her ex-husband Ted Hughes as Fascists, who she adored as every woman does. The poem shows how the fall of the paternal ideal at the age of eight, resurrected in her matrimony with Ted Hughes, repeats itself, and therefore she should kill them both to be through.
\end{abstract}

Keywords: Sylvia Plath, Confessional Poetry, Mad-Genius Paradox, 'Daddy,' Trauma

"It can happen that an author will kill himself or herself writing. The only book that is worth writing is the one we don't have the courage or strength to write ... It is combat against ourselves, the author; one of us must be vanquished or die." Helene Cixoux

\section{Introduction}

When we read a work of art like a piece of fiction, our focus is on the way the time passes, the way the plot progresses amid its conflict and catastrophe, but in a lyric poem there is a sense of intimidation that tends to stop time. That's the reason that lyrics tend to be short, and according to Edgar Allen Poe, not more than 100 lines. In fact the lyric tries to mitigate the 'tempus fugit' character of time, perhaps to allow moments of discovery where it makes us stop and wonder what life is about, and in that particular slice of life the clock doesn't tick. Northrop Frye (1996) says about the lyric poem that "The private poem often takes off from something that blocks normal activity, something a poet has to write about instead of carrying on with the experience...When the block ceases to be opaque and becomes transparent, the lyric of frustration

(c) AesthetixMS 2019. This Open Access article is published under a Creative Commons Attribution Non-Commercial 4.0 International License (http://creativecommons.org/licenses/by-nc/4.o/), which permits non-commercial re-use, distribution, and reproduction in any medium, provided the original work is properly cited. For citation use the DOI. For commercial re-use, please contact editor@rupkatha.com. 
expands into the lyric of mental focus" (pp. 131-132). The poet has to write about that block before returning to the world of Time. So, say for instance, you are paralysed by grief, you write a poem about loss. Poetry is what you write when you cannot do what you want to do. It is an "exploration of the deepest and most intimate experiences, thoughts, feelings, ideas: distilled, pared to succinctness, and made music to the ear by lyricism." (Bolton, 1999, p. 121)

It is perhaps because of this that lyric poets end up in insanity. It is not only Sylvia Plath, but also so many of them, like Edgar Allen Poe, Hart Crane, John Berryman, Robert Lowell, and there is a long list of casualties. Kafka, who "wanted to turn his premature natural death from tuberculosis into artistic suicide by having all his writings destroyed," (Alvarez, 1966, p. 258) perhaps just circumvented it. The world won't be richer had Hemmingway and Woolf, and Dickinson been cured of their distinctive illnesses. Literary genius and mental illness grew synonymous and lent interrogative points to ponder to revise our diagnostic methods and concepts. We wonder and we do try to explore this dangerous habitat, the world of the lyric, and we send other people to explore for us. We send artists to such space-times because we cannot afford to go there, as it is too scary for us. We lack the tool to depict that indescribable world. The irony is that those who have the tool to create a link with our world linger and languish there in such a way that is self-destructive. That could be an explanation for art to exist in that way, or perhaps we need artists to sacrifice themselves for us, to live in those scary hyphenations that ultimately kill. The paradigm of "dirty text" ${ }^{1}$ furthers the idea that Plath explored the hyphenated space between life and death passionately, and doing so, she tried to put back the filth of suffering into perspective, instead of excising it like others, which involved scavenging on the selfdestructive testimony of infliction. Perhaps, it is in these moments that she probed that narrow area that was overwhelmingly violent, which can be transformed into poetry, and that which is self-effacing, trying to stop time, to live in time that is utterly inescapable, and in the process, weaving the intense lyrical poetry.

This essay aims at dealing with three strands. Firstly, it deals with the question of the choice of the genre in which Sylvia Plath mostly wrote. Secondly, it traces the link between mental illness and creativity, what we also know as Mad-Genius Paradox, and how this assumption fits in exploring the link between Sylvia Plath's neurosis and her genius and her huge emotional investment in literature and poetry. Thirdly, explicating lines from her poem 'Daddy' for demonstrating that her mental sickness had roots in her father's early demise, and which culminated in her suicide following the break-up of her marriage with Ted Hughes. The essay thus concludes that a veritable link exists among the above three strands that needed addressing. Though Sylvia's choice of celebrating the Confessional form could be seen as an attempt at catharsis, but 'Daddy' shows the project failed, and what remained is the question, if she was through?

\section{Confessional Poetry and Sylvia Plath}

For T. S. Eliot, the secret to writing great poetry was to strive to what he called a continual extinction of personality. The idea was that by suppressing his or her own emotions poets can harvest the collective experience of those emotions that cause such an extinction of personality or the 'self.' Plath's poetry, especially earlier ones were written in that tone, but by the time she started Ariel, her poetry became more and more personal and highly subjective. Most of Plath's poems provoke two assumptions; first, that there are real events that inspire her text, and second, that somebody is Sylvia Plath herself and not like Eliot's alter ego Pruffrock. These assumptions are the reasons that Sylvia Plath's critics describe that this kind of poetry is rather confessional. 
Interestingly the term "confession" by itself is metaphorical because it is generally used in a religious context, where it means confessing one's sins to a priest or admitting having done something wrong. Miranda Sherwin (2011) points out: "The poet becomes the sinner, the poems become acts of penance, and the readers become priests. This latter role is at once the most interesting and the most troublesome, as it obliges readers to judge poets for their sins" (p. 25). Confessional poets reflect on subjects such as mental and physical illness, domestic breakdown, and sometimes about sexual dissatisfaction or frustration, and functions of the female body (menstruation, pregnancy, childbirth, miscarriage or abortion), in tandem with the problems of the modern world. Beach (2003) explains:

The appeal of confessional poetry was heightened by its seemingly direct portrayal of poets' tempestuous lives. In fact, it was often the biographies of the confessional generation as much as their poetry that attracted the attention of scholars, critics, and readers. Plath, Berryman, Anne Sexton, and Delmore Schwartz were all suicides, and Jarrell attempted suicide. Other confessionals experienced problems with alcoholism (Lowell, Bishop, and Berryman), emotional breakdowns and depressions (Lowell, Berryman, Bishop, Plath, and Sexton), and divorces (Lowell, Berryman, Jarrell, and W.D. Snodgrass). (p. 155)

Confessional poetry deals with a conversational style to express or confess intimate and more often painful experiences from the poet's own life events. Confessional poetry is known for its radical break from Modernist poetry with its impersonal theory of poetry, not only because Eliot's poetry was never impersonal, and had it been so it would have been horrible. Perhaps it looked impersonal. 'Confessional' was the term Robert Lowell generally used for his own poetry since the publication of Life Studies in 1959. The term was first used in 'Poetry as Confession,' a review of Life Studies' by M.L. Rosenthal. Lowell's approach of poetry led to the recognition of confessional poetry as a genre, though Rosenthal regretted using the term, and said, "Whoever invented it, it was a term both helpful and too limited, and very possibly the conception of a confessional school has by now done a certain amount of damage" (as cited in Harris, 2003, p. 26). The Oxford Concise Dictionary of Literary Terms offers the following definition (italics mine):

Confessional poetry: an autobiographical mode of verse that reveals the poet's personal problems with unusual frankness. The term is usually applied to certain poets of the United States from the late 1950 os to the late 196os, notably Robert Lowell, whose [works] deal with his divorce and mental breakdowns... Other important examples of confessional poetry are... Sylvia Plath's poems on suicide in Ariel (1965). The term is sometimes used more loosely to refer to any personal or autobiographical poetry, but its distinctive sense depends on the candid examination of what at the time of writing were virtually unmentionable kinds of private distress... (Confessional Poetry pp. 48- 49).

Also, confessional poems are the revelation of personal trauma that aims at cathartic or socially subversive purposes, and the necessary origins of the poem's subject matter in biography. Ropert Philips (1973) said "All confessional art, whether poetry or not, is a means of killing the beasts which are within us, those dreadful dragons of dreams and experiences that must be hunted down, cornered and exposed in order to be destroyed" (p. 2). Confession for Sylvia Plath is the process of remaking the self through a continual assertion for the self as a subject of the poeisis. And she had a lot to confess, with memories of home where Atlantic was on the one side and the Boston harbour on the other, and later when she moved with her parents to mainland to the west of Boston, or when she went to Smith College, in her third year, when she was twenty years old and was diagnosed for depression. With a symbiotically suffocating mother and a dead 
father who was medically self-negligent, Sylvia attempted a suicide soon when she swallowed a bottle of sleeping pills, about which she says, "I swallowed quantities and blissfully succumbed to the whirling blackness that I honestly believed was eternal oblivion." (as cited in Meyers, 2018, p. 96 )

Plath went to Cambridge on a full scholarship and all along she had been writing poems, though her first poem was published in Boston Herald when she was eight. She never stopped. She was just never satisfied, she thought she would never be a real writer, and decided to go for a marriage, and when she met Ted Hughes in a literary party at Cambridge, the story goes, that on her first meeting she recited one of his poems from her memory, and after the first kiss, she bit Ted Hughes on the neck and he bled and that was their kind of love. In a year's time they married on the Bloom's day. Plath published The Colossus the following year. Then she published her first novel The Bell Jar under the pseudonym Victoria Lucas. In 1962 Plath discovered that Ted had an affair, and they separated. Over the next few months she wrote most of her 'Ariel' poems, remarkably powerful and highly charged with emotions. She says, "Every morning, when my sleeping pill wears off, I am up about five, in my study with coffee, writing like mad - have managed a poem a day before breakfast. All book poems. Terrific stuff, as if domesticity had choked me" (1999, p. 550). In these last poems, she was systematically probing that narrow, violent area between the viable and the impossible, between experience, which can be transmuted into poetry, and that which is overwhelming.

After her death, the presence of Ted Hughes lingered for what we know of Plath's poetry. Was there any influence on one another for those six years of togetherness and for the rest of Ted Hughes' life after Sylvia's death? Since she did not leave any will, Ted Hughes was in charge of Plath's manuscripts. After her death, Hughes slowly released her manuscripts over the next thirty years. Hughes rearranged the order of the Ariel Poems. This was the magnum opus of Sylvia about which Robert Lowell says, "Everything in these poems is personal, confessional, felt, but the manner of feeling is controlled hallucination, the autobiography of a fever" (as cited in Brian, 2016, p. 165).

Plath's choice in writing confessional poetry was her way to celebrate the burden of experiences of both her past and present life. She excelled in the genre and made it difficult, forever, to read her poems away from her life. In a journal entry from late 1958 she wrote, "I felt if I didn't write nobody would accept me as a human being. Writing, then, was a substitute for myself: if you don't love me, love my writing \& love me for my writing. It is also much more: a way of ordering and reordering the chaos of experience" (Plath and Kukil, 2014, p. 448). Tracy Brain (2014) observes, "Few critics or readers would dispute the idea that interpretation is affected by foreknowledge. Of course, readers cannot "un-know" what they know, but the packaging of Plath's work ensures that they are predisposed to "know" as much as possible about the connection between her life and her writing before they even begin to read" (p. 8). Rosenthal claims Plath's first volume of poetry's "bearing is clearer and more harshly moving now that Ariel and The Bell Jar have illuminated the mind behind them for us. I feel rebuked not to have sensed all these meanings in the first place, for now they seem to call out from nearly every poem" (as cited in Wagner, 2007, 34).

Betty Friedan's (2001) statement that "Women are human beings, not stuffed dolls, not animals. (...) education for women has become so suspect that more and more drop out of high school and college to marry and have babies; (...) women so insistly confine themselves to one role" (pp. 6o-61), can be a partial explanation of Sylvia's suburban musings in the sense that Plath settled down with marriage, and that didn't match her aspirations. Her job as a secretary to a 
Psychiatrist in 1959 "triggered a whole series of dark memories" (Butscher, 2003, p. 234). Although she claimed "I want, I think to be omniscient...I think I would like to call myself "The girl who wanted to be God." Yet if I were not in this body, where would I be-perhaps I am destined to be classified and qualified. But, oh, I cry out against it. I am I-I am powerful-but to what extent? I am I" (Plath, 1999, p. 40), her decision to work to circumvent the writer's block "served to remind her of a submissive feminine function she could not escape and the ancillary waste of her education" (Butscher, 2003, p. 234). Friedan earlier said "The feminine mystique says that the highest value and the only commitment for women is the fulfillment of their own feminity. (...) But the new image this mystique gives to American women is the old image: "Occupation: housewife"' (2001, p. 37). Sylvia couldn't reconcile with her marriage, the newfound 'occupation,' her urge to claim her identity as a poet.

Hélène Cixous' famous dictum "It can happen that an author will kill himself or herself writing. The only book that is worth writing is the one we don't have the courage or strength to write ... It is combat against ourselves, the author; one of us must be vanquished or die" (as cited in Hoag, 2018, p. 16) helps us unravel some clues to Plath's confessional mode, which is "unruly, hysterical, irrational, disintegrated, rhizomatic and creative" also "characterized by an anarchy whose ruthlessness would make it void of comprehension" (Pullen \& Rhodes, 2008, p. 245). It is not clear if Plath searched for therapeutic effect in writing poetry, but it cannot be ruled out that writing gave her some kind of strength to overcome some kind of weakness or perhaps suffering. Sexton managed to live up to 46 years of age. Moreover "Poetry writing is particularly appropriate for the depressed, the anxious, or those suffering from certain illnesses, physical or psychological (Bolton, 1999, p. 123). The issue "whether this means that poetry drives us insane, or that a very large number of mentally ill people turn to poetry writing" was not taken up by Bolton for it being "an under-researched area which deserves more scrutiny" (p. 123). I have tried to tackle this issue below.

\section{Sylvia Plath's is a Well-Bred Malaise}

Postmodern age is that of psychiatric complexities, and the poet is no exception, or shall I say all artists are sick. Freud said that art is a symptom of its author's mental problems. Whatever, if great art is really sick, it has given so many so much. Maybe we need to redefine disease and ailments of the mind, maybe what drives some poets mad to the point of suicide is not the world that we know as the world of art, perhaps it is the only world, and not their world that we call sick.

John Keats in 'Ode to a Nightingale,' wrote:

“...for many a time

I have been half in love with easeful Death,

Call'd him soft names in many a mused rhyme,

To take into the air my quiet breath;

Now more than ever seems it rich to die,

To cease upon the midnight with no pain". (Keats, 2009, p. 239).

And Anne Sexton was asked by her psychiatrist "You can't kill yourself, you have something to 
give. Why if people read your poems (they were all about how sick I was) they would think, "there's somebody else like me!" They wouldn't feel alone." Her biographer continues: “This was the message Sexton called her turning point: "I had found something to do with my life"” (as cited in Knafo and Kahoud, 2018, p. 70). Adrienne Rich said, "For writers, and at this moment, for women writers in particular, there is the challenge and promise of a whole new psychic geography to be explored. But there is also a difficult and dangerous walking on the ice, as we try to find language and images for a consciousness we are just coming into, and with little in the past to support us" (as cited in Gilbert and Gubar, 2007, p. 984). Anne Hudson Jones, who was a Professor of Medical Humanities, working on the same awareness as Adrienne Rich, says, "The physician and the poet can both be healers. They share a common goal in their efforts to maintain light and order against the chaos of darkness and disease, and to create or restore the beauty and harmony of health: in this quest, medicine serves the body, poetry the spirit" (as cited in Bolton, 1999).

The therapeutic value of creative writing, especially poetry, is far greater than just the catharsis of those emotions that sustain pathology in the writer. It gives the author clarity of thought with graphical visuals in the background as a result of the controlled poetic outpour of the powerful precursors of emotional suffering. Frampton says, "One reacts, not just to what is written but to what seems to hover around it unwritten" (as cited in Bolton, 1999). It should be remembered that not all therapeutic writing is art. A bleeding heart, an angst, or the dread of the consequence may be cathartic, but all this splurge may not be a poem. But great poems like that of Sylvia Plath "offer alternative models or maps of suffering, pain management, adaptation, and healing work" (McEntyre, 2011, p. 456). Anne Sexton doubted the therapeutic value of literature, and this could easily be applied to Plath when she says, "You don't solve problems in writing. They're still there. I've heard psychiatrists say, "See, you've forgiven your father. There it is in your poem." But I haven't forgiven my father. I just wrote that I did" (as cited in Maio, 2005, p. 5). This is what I call a well-bred malaise in Sylvia, the consistent nurturing of deep-seated animus against her father. Feirstein (2016) claims that Plath's works are "a pathological displacement of rage at her good-enough mother Aurelia onto her male figures" (p. 104). I agree very little with this, only to the extent in Freudian sense, and I feel that Feirstein has not shown substantially what he claims. On the contrary he says that "Edge" and "Daddy" are among Plath's least obscure poems" (p. 121). If 'Daddy,' with which I deal below, is not obscure, there is a certain 'dead father effect,' a term first used by French psychoanalyst André Green.

Butscher (2003) wrote that Plath had told Nancy Hunter and others "the new truth: her father was a tyrant whom she wished dead and then felt terribly guilty about when he did die....the fierce rage Sylvia felt (and continued to feel unconsciously) towards her father precisely because he had died and abandoned her" (Butscher, 2003, p. 234). Susan E. Schwartz (2017) studied the 'dead father effect' in Sylvia's case and says, "A father's absence and emotional deadness can fuel a daughter's compensatory drive towards heroism and fame, or equally it can ignite the flames of depression and self-doubt. Trapped under his spell she might live provisionally-time passing without meaning or purpose. She wanders" (p. 219). Whatever, it was not her "self-inflicted tragedies" that she turned "into poetry" as Feirstein says (2016, p. 105). We, therefore, need to think whether it was Sylvia Plath's writing that made her depressed and eventually influenced her decision to commit suicide or was it was her depression and the mental sickness that influenced her poetry, what Chruszczewski (2014) calls "the creative side of mood disorder." I will examine below why and how creativity and mental sickness have been studied for a possible link.

Maladies of the mind, various kinds of depression, and creativity have manifested in some 
or the other form of eminence in creative writing since long. Chruszczewski (2014) says:

The first of them (see "Phaedrus", XXII, by Plato, IV ${ }^{\text {th }}$ century BC/1993) emphasised the affinity of art and madness, and argued that art - treated as being born from divine madness (mania sui generis) - is superior to all kinds of academism. Plato also stressed the particular proximity of that madness to poetry. The second of them, Aristotle, linked melancholia (which means depression or at least dysthymia in modern psychology terms) with eminence in various domains, not only artistic, but also in philosophy and politics (cf. "Problemata"1, XXX, 1 - Aristotle, IVth century BC/1980). The classical philosophers, could not have known the truth of, these ancient observations but they have been corroborated by the results of modern empirical research, according to which some psychological disorders have been found to correlate to varying degrees with creativity. (pp. 46-47)

Mark A. Runco (1998) cites Ludwig's investigation² into the relationship between mental sickness and creativity or extraordinary achievement, and gives a clue to 'Resolving the Creativity and Madness Controversy,' a phrase that is also the subtitle of the latter's book where he studied the lives of 1000 eminent people of the zoth century. He found that the highest attempted suicide rate, which was $26 \%$, belonged to poets, actors being at second with $23 \%$. He also noted that poets had the highest rate of emotional disorders, about $87 \%$ in his sample.

In another study, the lowest percentage of mental disorders was observed in the group of architects (17\%) and sculptors (18\%), it was somewhat higher in the group of painters (20\%) and was significantly higher among musicians (38\%). The highest prevalence of mental disorders was observed for the group of poets (50\%) (Chruszczwewski, 2014, p. 48). Chruszczewski (2014) cites Martindale who studied the biographies of forty well-known English and French poets and found that "the symptoms of severe psychopathology existed in about half of the poets included in the study (55\% for English poets, and 40\% for French poets)" (p. 48). Chruszczewski (2014) further cites Ludwig, who I have noted above, although he emphasizes that "any co- existence of creativity and mental disorders does not imply that affective disorders, or any others, are a prerequisite to creativity, even in exceptional forms" (p. 50), saying that "a psychometric assessment is not equivalent to clinical diagnosis." In the 'summary of the empirical results' Chruszczewski says, "it is necessary to emphasise the existence of a positive statistically significant association between creativity and affective disorders, bipolar in particular" (pp. 53-54).

Joscelyn E. Fisher (2015) reminds that 'creativity' is "likely composed of various facets" and 'mental illness' is "a heterogeneous construct that not only encompasses multiple symptoms and diagnoses but reflects societal and cultural definitions and norms, resulting in changes to diagnostic criteria sets throughout the years" (p. 1). Djikic and Oatley, while abiding with Silvia and Kaufman's "cautions" propose that:

[S]ituational factors, as well as factors specific to the production of art, are important. We propose that three qualities need to coexist in an artist, and are necessary for successful works of art to be made: sensitivity, emotion-driven preoccupation with exploration within a par- ticular medium of expression (which we call "artistic compulsion"), and lack of self-deception. (as cited in Silvia and Kaufman, 2010, p. 283)

It is inferred that creative "artists are more sensitive than others" (as cited in Silvia and Kaufman, 2010, p. 283). They live in a world that has heightened sensitivities and perceptions. Although Pickering et al (2016) contend and say that "Neurotic Individuals are not Creative Thinkers." The deadlock is solved with the help of Dean Keath Simonton's (2014) two 
propositions:

Proposition 1: Among all creative people, highly creative persons have higher rates of psychopathology than do less creative persons.

Proposition 2: Among all people, creative persons have lower rates of psychopathology than do noncreative persons. (p. 471)

Contradictory "at first glance," he goes on to claim that these two propositions are "not only true but also mutually supportive." He says, "As a group, creative people can be more mentally healthy than noncreative people. Yet among all creative people, those who ascend to the status of creative genius can exhibit more proclivities toward mental illness than creative colleagues who do not attain that high status." (p. 471) This is what we know as, and as Simonton calls it, the "madgenius paradox."

Alvarez (2002) was perhaps right in arguing that the modern poet is peculiarly committed to the truths of his inner life and to his art, which creates and is created out of that self that suffers. Such an inward quest for a sort of 'romantic agony' (Praz, 1991) fixes the artist between life and death. In his obituary on Berryman that Lowell wrote for The New York Review, he says:

I must say something of death and the extremist poets as we are named in often perfunctory tributes. Except for Weldon Kees and Sylvia Plath, they (i.e., Berryman, Jarrell, and Thomas) lived as long as Shakespeare, outlived Wyatt, Baudelaire, and Hopkins, and long outlived the forever Romantics, those who really died young. John himself lived to the age of Beethoven... . (Lowell, 1964)

Alvarez (1969) says that Sylvia was "ruthlessly efficient" at everything including poetry, but he adds "Poetry, however, is not made by efficiency-least of all Sylvia Plath's poetry. Instead, her extraordinary general competence was, I think, made necessary by what made her write: an underlying sense of violent unease" (p. 47). Mark A. Runco (1998) suggests that "Plath's huge investment in writing may have contributed specifically to her sensitivity and thus predisposed her to depression" (p. 638). He says that the concept of psychic investments provides "a very optimistic approach because they suggest that suicide is not just temperamental but at least partly a result of development and experience (i.e., the investments themselves)."Suicides, as I see, are often thought of well for weeks, or months, and sometimes even years, when things wax and wane in the lives of such people. For example Anne Sexton wrote about suicide long before her final draft in 1974. In her poem 'Wanting to Die' she writes:

But suicides have a special language.

Like carpenters they want to know which tools.

They never ask why build. (7-9)

On 11 February 1963, Plath stuffed towels under the doors of the bedroom of her children Frieda and Nicholas, and she put her head on the oven and lit the gas to a death that made historians shocked. She "[A]ttempted and succeeded in turning herself into a tragic, mythic heroine" (Fierstein, 2016, p. 103). But the curative power of art did not help her. Perhaps writing the book bound her to the horror within her. In Lady Lazarus she says "Dying / Is an art, like everything else. / I do it exceptionally well" (43-45). Linda Wagner Martin (2007) in her introduction to Sylvia Plath: The Critical Heritage says:

For a young woman to kill herself at the beginning of a successful writing career posed an intriguing-and frightening-mystery. All kinds of equations between art and life began to 
be suggested. Had Plath written so personally that she had somehow crossed the boundary between art and life? Was full exploration of the creative process dangerous? Why would a woman with two small children choose to leave not only her successful practice of her art but also those dependents? Controversy was rampant, and criticism of Plath's work would never again be untouched by biography. (p. 1)

Studying Sylvia's suicidology ${ }^{3}$ in medico-clinical terms in Psychiatry is beyond my the scope of the article, and the treatment of the term is limited to enumerating some of the major events in her life, what Shulman (1998) calls the "Vulnerability Factors," that can explain the link between the literature she produced and the thought processes that shaped and reshaped it. Her 'Psychache,' which can be explained as "the hurt, anguish, or ache that takes hold in the mind the pain of excessively felt shame, guilt, fear, anxiety, loneliness, angst" (Bryant and Peck, 2009, p. 826), has been studied since then, and conclusions have been made to come to terms that "Suicide is functional because it abolishes the pain for the individual. Suicide occurs when the psychache is deemed by that individual to be unbearable. It is an escape from intolerable suffering" (p. 827).

She wrote in her journal about her recent poems, "relating to my own father, the buried male muse and god-creator risen to be my mate in Ted" (Plath and Kukil, 2014, pp. 784-85) to discover soon "All stupidity and frankness on my side: what a fool one is to sincerely love . . . I made the most amusing, ironic and fatal step in trusting Ted was unlike other . . men" (Plath and Kukil, 2014, p. 806). The personal experience is definitely important but it shouldn't be just a shock and awe document. For her, it is to make the personal relevant, by showing the universal through the particular. Her fame rests on not only the way she died but also on the way she wrote.

Langdon Hammer (2001) asked "Was Plath a feminist martyr, a mass-culture doll, a dutiful daughter, a psychotic, a bitch-goddess, a major writer-or a minor, sensational one, a postmodern Chatterton?" (p. 68). Her success coincided with the perfect timing of her death that made her the poster girl of the American feminism, the decade of Betty Freidan, Gloria Steinem, etc., and Ted Hughes became the villain, the man in black, simultaneously. Robin Morgan in her poem 'Arraignment' writes "How can / I accuse / Ted Hughes / of what the entire British and American / literary and critical establishment / has been at great lengths to deny / without ever saying it in so many words, of course, / the murder of Sylvia Plath?" (as cited in Moulin, 2011, p. 22) The poem threatens to dismember Hughes and to sew up his lips. In such times Hughes had to avoid public readings of his poems. The surname Hughes was chiseled off from Sylvia's tombstone three times, perhaps as a result of such an invective. Hughes at last broke his silence just a year before his death in 1998, in a book titled The Birthday Letters, full of confessional poems addressed to Sylvia. The legend goes that he wrote one poem each year on her birthday. The book was a huge success in England, received almost like a scandal newspaper, but it was not received so well in America. The Birthday Letters clears the haze that surrounded the events of his life and Sylvia's afterlife, and it became clear that Hughes couldn't manage to escape the spectre of her death, by living, any more than she did by dying.

Dori Laub, who is not only a professor at the Yale School of Psychiatry, but also the cofounder of Fortunoff Video Archive for Holocaust Testimonies, says while beginning her essay on 'Testimony,' that she conceives "the process of the testimony as, essentially, a ceaseless struggle." Dori Laub's concept of 'Testimony' holds good on the speaker of 'Daddy' not only because there is a veritable past that haunts it and other poems as well written by Plath, but also because there is the indescribable act of suicide that she committed. Laub quotes a holocaust 
survivor "We wanted to survive so as to live one day after Hitler, in order to be able to tell our story" (Fortunoff, $\mathrm{T}_{5} 8$, as cited in Felman and Laub, 2012) to assert that she started to believe in just the opposite of this and she says that "The survivors did not only need to survive so that they could tell their stories; they also needed to tell their stories in order to survive" (p. 78). Does it mean Sylvia wanted to survive even after her death? Has she survived? Not in the sense Laub's witness wanted, but the other way round. There arises, thus, the question as to why poets write. Why does anyone write? What is it that lies in for anyone to tell the tale?

Plath's Ariel Poems, tempered with and tampered by her past, suggest her quick but intense response to her highly charged mental state that precipitated as a result of a long suffering that traces back to the death of a father. For her "He was the symbol of the vast personal and social pressures that had distorted her life...he was the cause for her retreat behind masks and prime instigator of the endless insecurity propelling her existence into a series of depression and manic explosions" (Butscher, 2003, p. 239). Schwartz (2017) says about this lingering effect on Plath, "the daughter remains psychologically shackled to the absent and dead connection. This becomes a cunning psychic pact made with the father not there, unavailable for catharsis or working it through. The example shows how the dead father image lives within, deadening her system" (p. 218). As a result "A father's absence and emotional deadness can fuel a daughter's compensatory drive towards heroism and fame, or equally it can ignite the flames of depression and self-doubt" (Schwartz, 2017, p. 219).

There is an inner conflict that persists and nurtures the very causes that it wishes to obliterate, a conflict that lies in the desire to overcome the diseased self. It builds up what Sarah Ditum (2017) calls "a furiously contested mythology" that shapes up the interventions between art and suicide. Jaworski (2012) argues that "we cannot depart from this world, or at least try to, without something paving the way for our intentions and desires to die. In this sense, it is possible to read suicide as relational - as never being outside discourse" (p. 35).

The third chapter of Fairbairn's (2013) Psychoanalytic Studies of the Personality, titled "Return of the Repressed Bad Object" portrays the inner conflict that Plath mythically converted into a Nazi ghetto. Harry Guntrip's (1969) Schizoid Phenomena: Object Relations and the Self, which helps us understand Plath's pathology, is one of the most extensive psychoanalytic works on the Plath's inner world. It clearly tells that "Plath's life and essentially autobiographical poetry and prose seem a series of illustrations for the false and true self" (Feirstein, 2016, p. 108).

Sylvia's illness rises from the mitigation of relationships, sort of bonds that could sympathize with her, had they were not broken, leading to the failure of assimilation of certain experiences that live dormant and manifest in the death instinct. It is thus a question as to how do we know Sylvia Plath as readers and as researchers - by her life or by her death? Does it present different perspectives if we deal with her as a writer than when we study her as a person? Indeed, given the final collection of Sylvia Plath's poems Ariel, which was published with two different orders of poems given by Ted Hughes her ex-husband and her daughter Freida, there arise newer dimensions, that not only link both the different perspectives somehow, but also put in piece a better analysis of the evasive but pertinent question of the dialectic between trauma and perpetration.

\section{'Daddy,' Trauma and the Freudian 'Muse'-ing}

Cathy Caruth (1995) defines Post Traumatic Stress disorder as: 
“...a response, sometimes delayed, to an overwhelming event or events, which takes the form of repeated, intrusive hallucinations, dreams, thoughts or behaviors stemming from the event, along with numbing that may have begun during or after the experience, and possibly also increased arousal to (and avoidance of) stimuli recalling the event. This simple definition belies a very peculiar fact: the pathology cannot be defined either by the event itself-which may or may not be catastrophic, and may not traumatize everyone equally-nor can it be defined in terms of a distortion of the event, achieving its haunting power as a result of distorting personal significances attached to it. The pathology consists, rather, solely in the structure of its experience or reception: the event is not assimilated or experienced fully at the time, but only belatedly, in its repeated possession of the one who experiences it. To be traumatized is precisely to be possessed by an image or event. And thus the traumatic symptom cannot be interpreted, simply, as a distortion of reality, nor as the lending of unconscious meaning to a reality it wishes to ignore, nor as the repression of what once was wished. (pp. 4-5)

I would not quote such a long passage but for its sheer clarity in explaining how Sylvia's mental state and the events in her life fit the above paradigm. There is no simple access to such a crisis in the traumatised person who tends not to speak in the heat of the moments of traumatic experiences, and if "trauma is rendered unspeakable because it is too dirty and dangerous, a filthy stray dog scavenging on the margins, unfit to be let into our house of words" (Tamas, 2011, p. 444), it is the belatedness and delay that lends acuity to the crisis of survival. She was a survivor of trauma, at least twice, officially. Hers is not a case of either repressed wishes and instincts, or actual memories, but both. And that is where the term Freudian comes to rescue. Though there has been a great deal of development in the field of psychoanalysis and psychopathology, approaches to such illnesses remain Freudian fundamentally.

Antoon A. Leenaars and Susanne Wenckstern (1998), who have done a 'protocol analysis' of Sylvia Plath's last poems, studied suicide notes, diaries, etc. of those who committed suicide and found poems at almost equal footing, as documents that tell the tales of trauma before suicide. They say, "Poems have always been seen as a looking glass, being open like the diary and suicide note, to understanding the human mind. This is especially true about the poems left before suicides, although, of course, they are likely written to be more public than the note but not more public than many diaries."

Plath wrote the poems she planned to be called Ariel, in all 41, primarily during the fall and winter of 1962 "at about four in the morning - that still, blue almost eternal hour before the cockcrow, before the baby's cry" (as cited in Alvarez, 2002, p. 71). She left the completed manuscript on her desk, before her suicide in February 1963, arranged neatly in a black binder, perhaps to be discovered later by Hughes. Ariel, as many critics say, is one long suicide note. It is a gale of paroxysm at the emotional mistreatment of her husband, and an almost unwarranted frenzy of anger against her father. Her poems are perceived in a rehashed form because of the suicide, which gives reason to pause and ponder. This perception leads us to a "confusion ... because suicide is interpreted mostly from an observer's perspective, because the dead are not in the habit of confirming external observations" (Jaworski, 2012, p. 33). The fame of Ariel rests largely on one poem, the very much known 'Daddy,' "the Guernica of Modern Poetry" (Steiner, George in Wood, Nigel and David Lodge, 2014, p. 798). Sylvia Plath described 'Daddy' as:

spoken by a girl with an Electra complex. Her father died while she thought he was God. Her case is complicated by the fact that her father was also a Nazi and her mother very possibly part Jewish. In the daughter the two strains marry and paralyse each other - she 
has to act out the awful little allegory once over before she is free of it. (as cited in Martin, 1997, p. 196)

The beginning of the poem is where a lyric should begin, as I mentioned earlier, like a blocked activity, something the poet cannot do, and here she cannot bury her father till she resolves to change the situation in the second line "any more black shoe." The next line "Daddy I have had to kill you" poses questions in grammar; one can't have an ongoing murder, it is for good. But it makes sense in her case because her father "died before" she "had time to grow up." As she later recalled, "He was an autocrat. I adored and despised him, and I probably wished many times that he were dead. When he obliged me and died, I imagined that I killed him" (Steiner, 1978, p. 13).

Freudians would say that children tend to try to become autonomous from their parents. For Sylvia, she was not allowed to separate from her father as he died too early, and unfortunately she was not allowed to attend her father's funeral. She lost her connection to the past with that. She doesn't know his past and she says that in the poem that his past is scraped flat by the war machine, 'I never could tell where you put your foot / It stuck in barbwire snare / I could hardly speak.' She misses that past, and therefore misses her self, and therefore she cannot speak 'I' but says "ich ich ich."

When she recorded 'Daddy' for the BBC in Oct. 1962, the interviewer asked her if she thought the poem comes from books or from her life. She replied that she was mostly guided by her own experiences in life. Though she also added that she was not interested in writing just the 'cries from the heart' she thought that an artist should be able to control any personal experience, even if it is horrible, and to shape them in a larger than the self and more permanent and universal through the particularly personal. There is a good deal of controversy on 'Daddy' for it being a misleading body of evidence implicating her father instead of her mother, perhaps because Sylvia wrote in one of her journal entries:

Read Freud's Mourning and Melancholia this morning.... An almost exact description of my feelings and reasons for suicide: a transferred murderous impulse from my mother onto myself: the "vampire" metaphor Freud uses. "draining the ego": that is exactly the feeling I have getting in the way of my writing: Mother's clutch. (Plath and Kukil, 2014, p. 918)

Feirstein (2016) says that her portrayal of her father is "distorted," with which I agree in its most literal sense, but the cause of a distorted portrayal of her father lies in his early death and other abandonments. "These abandonments, along with her in-and-out schizoid personality and bouts of mania and depression (for which she was given primitive electroshock and insulin treatments), caused Sylvia to become stuck in a psychic muddle from which-despite her will and artistic power-she was unable to extricate herself" (p. 104).

In 1958 Plath wrote about Ted Hughes, "Do we, vampire-like, feed on each other? A wall, sound-proof, must mount between us. Strangers in our study, lovers in bed. " (Plath and Kukil, 2014, p. 870) The same year she wrote, "We are amazingly compatible. But I must be myself make myself and not let myself be made by him" (Plath and Kukil, 2014, p. 246). When we read 'Daddy' we find how she had endured trauma for years. And her meeting with Ted Hughes, marriage with him, and divorce later, overwhelmed her. Marriage with Ted Hughes was perhaps her attempt to fill the void that the demise of her father created. She found a replacement:

You stand at the blackboard, daddy, In the picture I have of you, 
A cleft in your chin instead of your foot

But no less a devil for that, no not

Any less the black man who

Bit my pretty red heart in two.

I was ten when they buried you.

At twenty I tried to die

And get back, back, back to you.

I thought even the bones would do.

But they pulled me out of the sack,

And they stuck me together with glue.

And then I knew what to do.

I made a model of you,

A man in black with a Meinkampf look

And a love of the rack and the screw.

And I said I do, I do . . . (Plath, 1966, pp. 50-51)

Perhaps early parental loss and later suicidal behavior are linked in many cases. Volkan and Zintl (1993) say, "Until a child has completed adolescence . . . a parent's death is by definition full of unfinished business. The child still needs the parent as a model and a source of love and approval"(p. 59). On the top of it Sylvia couldn't attend her father's funeral because her mother didn't allow her to, and she visited the grave only twenty years later with Hughes for the first time. Attending the funeral of a loved one "is a crucial part of the acceptance of the death," the bereaved person deprived of funeral attendance may be "unable to progress through the grieving process, because no goodbye has been said, no acknowledgement of death has been made" (Horn cited in Shulman, 1998). She said that she was tempted to dig her father's grave up to prove that he existed. She was denied psychologically what she had to enact metaphorically in her poetry, over and over again, killing the father. 'Daddy' is an effort to lay her father to rest. She thought of the title as 'Daddy Daddy Lie Easy Now' earlier.

Another way to look at the problem of the speaker in the poem is to see the rupture of her connection with the past, and her efforts to search for her identity. She says in the poem that her father's past in Germany has been scraped flat by war, by the tanks. She can't even find the town that he came from. "I never could tell where you put your foot, your root. I never could talk to you, the tongue stuck in my jaw. In a barb wire snare. Ich ich ich. I could hardly speak." Because she has no past she has no self, a sense of who she is. She knows she has a German heritage, but she can't say I in German. It gets stuck in her throat, and she is trapped in a snare. Her association with Holocaust survivors has always been an issue for critics and readers of her poems.

The assumption of a Jewish identity by the speaker of 'Daddy' is, by all means, an issue to be reckoned with. She internalizes victimhood, though we see that the poem addresses the externalization of perpetration, and while the speaker of the poem never lets the maternal ideal fall into the lines of fire she assumes a Jewish identity against the Nazi replacement father. For her Nazis were not only powerful authoritative replacement killers but also replacement fathers. She finds herself posed "like a Jew" or "a bit of Jew" against the tropes of Holocaust: the Swastika, the trains, the camps, etc. She addresses her father repeatedly as 'you,' though when she comes to herself her identity is uncertain and she can hardly speak. 
Plath, who is also the speaker in 'Daddy,' finds herself to be in the position of her father's victim while she should have rather inherited the role of 'victim' from her mother's side. She identifies herself as a victim at the hands of her 'daddy' but she doesn't identify herself with the Nazi perpetrators by rejecting any connection with him in the form of what could have been called a 'nirvana' instead of a literary parricide that made her a star overnight, at least in the commercial sense. Butscher (2003) says:

The final irony, in a career dedicated to literary irony, was the commercial success and critical acclaim that greeted Sylvia's work after her death, along with her near deification.

The latter took the form of a romantic reading and perverse worship of her suffering with the result that her biography appears more important than her poetry. (p. 364)

Her father's memory "both as a source of inspiration and as an oppressive force that makes finding one's own voice (particularly if one is a woman) tremendously difficult" (Rietz, 2007, p. 418), informs her intrusive past. Plath, to an extent, mourns her father in a typical Freudian sense to appropriate the loss of an object of desire, though it is also an insult to the ego. She says "I mask my self-abasement (a transferred hate of her) and weave it with my own real dissatisfactions in myself until it becomes very difficult to distinguish what is really bogus criticism from what is really a changeable liability" (Plath and Kukil, 2014, p. 918). Peel argues that, due to her father's death 1940, she

"...had been denied (because he had not lived) the direct experience of his noncomplicity, of his difference. She has not seen her father rejecting the tyranny that came out of Germany. What survives is the photograph of man (sic) with a postage-stamp moustache, and the memory of a man who delegated the care of his children to his wife. His image becomes confused with the ideology that his nation has spawned. Consequently, Plath identifies (sic) with his/their victims." (Peel, 2002, pp. 185-86)

To some extent this vanishing in-between sort of inexplicable space looms large especially when we realize that the speaker of 'Daddy' is also the daughter of Otto Plath, who is at last exorcised after the narrator invokes the tropes of Holocaust such as the concentration camps, the chuffing trains and the swastika. The assumption of a Jewish identity by the speaker of 'Daddy' is, by all means, an issue to be reckoned with. She internalizes victimhood, though we see that the poem addresses the externalization of perpetration, and while the speaker of the poem never lets the maternal ideal fall into the lines of fire she assumes a Jewish identity against the Nazi replacement father. For her Nazis were not only powerful authoritative replacement killers but also replacement fathers. She finds herself posed "like a Jew" or "a bit of Jew" against the tropes of Holocaust: the Swastika, the trains, the camps, etc. She addresses her father repeatedly as 'you,' though when she comes to herself her identity is uncertain and she can hardly speak.

The demonization of 'daddy' is a tool to detach from the evil, something that is extraordinary or perhaps extraterrestrial. "The evil doer who is a monster is removed from us, placed in a category outside of the human; for if evildoers are demonic monsters, they can be accounted for by jettisoning them from the category of "human beings", from the "we"” (Geddes, 2003, 106). Evil is by large not synonymous with the death instinct. During those times when reality is not completely forsaken but tools of defence mechanism are supplied by derivatives of death instinct we can see what we call neurosis manifesting in symptoms like amnesia, denial, fugue states, etc. at this point the realm of psychosis looms large and at time obfuscates the diagnostic framework. 
Hanna Segal (1993) writes of the death instinct that "in relation to the experience of needs, there can be two reactions: one, to seek satisfaction for the needs: that is life-promoting and leads to object seeking, love, and eventually object concern. The other is the drive to annihilate the need, to annihilate the perceiving experiencing self, as well as anything that is perceived" (p. 55). Jarowski (2003) argues that suicide like any other potential behavour is a behavior potential in all of us. Someone capable of living happily is equally capable of suicide if the "agonies and furies" become too much.

The death instinct is let loose as a denominator of trauma and its underlying experiences. In the poem 'The Thin People,' Plath's central focus is the survivors of the concentration camps instead of archetypal images as used in Ariel Poems. Atina Grossman (2002) reads it as a modern expectation, and she says "Given our own inflationary romance with the language and theory of trauma and memory and its corollary valorization, one might even say sacralisation, of Holocaust survivors, it is salutary to recall how very unromantic, unappealing, and alien the DP survivors appeared, even to those who meant to aid them" (p. 298).

\section{Conclusion}

The appeal of confessional poetry lies mostly in lyrics written by poets who choose the confessional form, and the choice is rather a result of their tempestuous lives that they live fast and furious. Plath's life was blotched with trauma, manic-depressive disorder, and posttraumatic stress disorder. I leave it to the reader to analyse 'Daddy' in its entirety, and if possible supplement it with the reading of 'Lady Lazarus,' which "ends by destroying husbands as father surrogates, tormenting them, identifying with the tormentor and using his methods" (Schwartz, 2017, p. 224). The results of the above discussion suggests that 'Daddy' is undoubtedly the work of a genius, and that genius could be associated to traits related with psychoticism. When we study the role of cognitive disinhibition in the creative process, we see that "[T]o a certain degree, creativity requires that the person not filter out putatively extraneous ideas...allowing the individual to "think outside the box." ...In fact, this mental proclivity is positively associated with elevated scores on psychoticism" (Simonton, 2014, p. 476)

Sylvia Plaths's fame owes not only to her suicide but also to her art as artistic success, through storytelling in the most intense poems of her life in Ariel Poems. These lyrics are symbolic of that block that demonstrates clear internal transformations of external experiences. Her lyrics are the "return of the repressed" (Freud, 1939, p. 129) and "They represent the rupture of in the web of meaning, the break of order and continuity-a dark and inconceivable boundary that provides the frame for the construction of meaningful histories but has no meaning by itself. Only later on, after a period of latency, can it be remembered, worked through, and spoken out" (Giesen in Alexander, J.C. et al, 2004, p. 113). 'Daddy' is just one of these lyrics.

Whichever way one tries to approach Sylvia Plath and/or her poems, one finds that she lived, like any other survivor of trauma, "in two different worlds: the realm of the trauma and the realm of their current, ordinary life" (Kolk, van der and van der Hart in Caruth, 1995, p. 176). This, largely, fades the distinction between her poiesis (poetic formation) and narration (story telling or recounting). Her choice of the confessional form is guided by her mental state that is markedly sick. 'Daddy' is an extremely significant event in her life that shows how the fall of the paternal ideal at the age of eight, resurrected in her matrimony with Ted Hughes, repeats itself. Her claim in the poem that "If I've killed one man, I've killed two-_ / The vampire who said he was you" helps her "soften the intrusive power of the original, unmitigated horror" (Caruth, 1995, p. 178). 
Ted Hughes said of himself and Sylvia that "And we / Only did what poetry told us to do" (Hughes, 1998, p. 68) with which I don't agree for his part. It can be said for Plath, not because she committed suicide, but because she wrote her best poems in the worst moments of her life and that tells something. Perhaps she conveys that you can do without poetry until you fall off, until somebody you love dies, until something goes terribly wrong, or terribly right. And when that happens poetry becomes not just essential but absolutely necessary. It could be one reason that art exists. We need artists to sacrifice themselves for us to go to places where we are not capable to tread, something that is a link between creativity and suicide. Literary supremacy and mental illness seem to go hand in hand, and perhaps we need to redefine mental illnesses, if that is the case. If literary genius and mental illness is synonymous it is our diagnosis that needs therapy. They say all art is sick, we are all messed up but artists are especially messed up. If great art, which really is sick, and it gives so much, we need to rethink and redefine our diagnostic methods and our criteria of defining mental illnesses.

Had 'Daddy' actually resulted in a substantial psychic release Plath would live on, though the unequivocal rage of the poem is reminiscent of the cathartic method. The final words "I am through," as they suggest, are an attempt at a testimony that survivors of trauma would like to give. Dori Laub goes on to ponder on the issue and says:

This imperative to tell and to be heard can become itself an all-consuming life task. Yet no amount of telling seems ever to do justice to this inner compulsion. There are never enough words or the right words, there is never enough time or the right time, and never enough listening or the right listening to articulate the story that cannot be fully captured in thought, memory, and speech. The pressure thus continues unremittingly, and if words are not trustworthy or adequate, the life that is chosen can become the vehicle by which the struggle to tell continues. (78)

Sylvia Plath's life and her poems are a study in testimony, a testimony of trauma that made her vulnerable to manic-depressive disorder and posttraumatic stress disorder. One may stop "to ask how we can listen to trauma beyond its pathology for the truth that it tells us" (Caruth, 1995, p. vii), the answer is the testimony that Plath's life and her works give. I am not sure if I have been successful in establishing that highly creative people like Plath are prone to psychosis, but I am sure of establishing at least one thing, and that is our inability to create poetry like Plath's while we live away from spectacles and "the blood jet" that "is poetry" (Plath, 1966, p. 82).

William Carlos Williams wrote, "men die miserably every day / for lack / of what is found" in "despised poems" (as cited in Mariani, 2016, p. 1326). The American poet Thomas Lynch (2011) replied to the above statement:

I tell...what the old doctor, William Carlos Williams meant when he wrote that men die everyday for what they miss in poetry. I tell him people are born, and reborn, everyday, who owe their very beings to poems. (p. 124)

Perhaps Frieda and Nicholas literally owe their lives to poetry. 
i. Pullen and Rhodes' concept of dirty text, in turn borrowed from George Marcus' (1994) idea of 'messy text' as cited in Sophie Tamas (2012).

ii. Arnold M. Ludwig is a known figure in Psychiatry at Brown University School of Medicine. He is Emeritus Professor of Psychiatry at Kentucky Medical School. He was also on the editorial board of Creativity Research Journal in 1995.

iii. The term as well as the concept was first used by Shneidman (1965). It has since been used in a number of ways.

\section{References:}

Alexander, J. C., Eyerman, R., Giesen, B., Smelser, N. J., \& Sztompka, P. (2004). Cultural trauma and collective identity. Univ of California Press.

Alexander, J. C. (2006). The meanings of social life: A cultural sociology. Oxford: Oxford University Press.

Alvarez, A. (2002). The savage god: A study of suicide. A\&C Black.

Beach, C. (2003). The Cambridge introduction to twentieth-century American poetry. Cambridge, UK: Cambridge University Press.

Bolton, G. (1999). 'Every poem breaks a silence that had to be overcome’*: The Therapeutic Power of Poetry Writing. Feminist Review, 62(1), 118-133.

Brain, T. (2014). The Other Sylvia Plath. Routledge.

Bryant, C. D., \& Peck, D. L. (Eds.). (2009). Encyclopedia of death and the human experience (Vol. 1). Sage.

Butscher, E. (2003). Sylvia Plath: Method and madness. Tucson (Ariz.: Schaffner Press.

Caruth, C. (1995). Trauma: Explorations in memory. Baltimore: Johns Hopkins University Press.

Clark, H. L. (2005). Tracking the thought-fox: Sylvia Plath's revision of Ted Hughes. Journal of Modern literature, 28(2), 100-112.

Chruszczewski, M. H. (2014). The Creative Side of Mood Disorders.

Djikic, M., \& Oatley, K. (2014). 13 On the fragility of the artist: art's precarious triad. Creativity and mental illness, 281.

Fisher, J. E. (2015). Challenges in determining whether creativity and mental illness are associated. Frontiers in psychology, 6, 163 .

Flaherty, A. W. (2015). The midnight disease: The Drive to Write, Writer's Block, and the Creative Brain.

Freud, S. (1939). Moses and Monotheism. Place of publication not identified: Hogarth Press.

Friedan, B. (2001). The Feminine Mystique. 1963. New York.

Frye, N., \& Denham, R. D. (1996). Collected works of Northrop Frye. Toronto: University of Toronto Press.

Geddes, J. L. (2003). Banal evil and useless knowledge: Hannah Arendt and Charlotte Delbo on evil after the holocaust. Hypatia, 18(1), 104-115.

Giesen, B. (2004). The trauma of perpetrators. Cultural trauma and collective identity, 112-154.

Gilbert, S. M., \& Gubar, S. (2007). The Norton anthology of literature by women: The traditions in English. New York: W.W. Norton.

Grossmann, A. (2002). Victims, villains, and survivors: gendered perceptions and self-perceptions of Jewish displaced persons in occupied postwar Germany. Journal of the History of Sexuality, 11(1), 291-318. 
Hammer, L. (January 01, 2001). Plath's lives: Poetry, professionalism, and the culture of the school. Representations, 75, 61-88.

Harris, J. (2003). Signifying pain: Constructing and healing the self through writing. Albany: State University of New York Press.

Hoag, T. (2018). Occupying memory: Rhetoric, trauma, mourning. Lanham: Lexington Books.

Hughes, T. (1998). Birthday letters. London: Faber and Faber.

Jaworski, K. (2003). Suicide and gender: Reading suicide through butler's notion of performativityı. Journal of Australian Studies, 27(76), 137-146.

Jones, A. H. (1997). Literature and medicine: physician-poets. The Lancet, 349(9047), 275-278.

Keats, J., \& Campion, J. (2009). The complete poems and selected letters. London: Vintage Classics.

Knafo, D., \& Kahoud, D. (2018). Sex, drugs and creativity: Searching for magic in a disenchanted world. Plath, S. (1982). T he journals of Sylvia Plath. New York: The Dial Press.

Lowell, R. (1964, May 28). The Poetry of John Berryman. The New York Review of Books. https://www.nybooks.com/articles/1964/05/28/the-poetry-of-john-berryman/

Lynch, T. (2011). The undertaking: Life studies from the dismal trade.

Maio, S. (2005). Creating another self: Voice in modern American personal poetry. Kirksville, Mo: Truman State Univ. Press.

Mariani, P. (2016). William carlos williams: A new world naked. Place of publication not identified: Trinity University Press.

McEntyre, M. (2011). Patient Poets: Pathography in Poetry. Literature Compass, 8(7), 455-463.

Meyers, J. (2018). Tragic Destinies. Salmagundi, (200/201), 85-244.

Moulin, J. (2011). The problem of biography. The Cambridge Companion to Ted Hughes, 14-26.

Peel, R. (2002). Writing back: Sylvia Plath and Cold War politics. Madison [NJ: Fairleigh Dickinson University Press.

Phillips, R. S. (1973). The confessional poets. Carbondale: Southern Illinois University Press.

Plath, S. (1962, Jul 06). Suffering angel. New Statesman, 64, 828.

Plath, S. (1966). Ariel : poems. New York (N.Y.: Harper and Row.

Plath, S. (1999). Letters home. Faber \& Faber.

Plath, S., \& Kukil, K. V. (2014). The *journals of Sylvia Plath: 1950-1962: transcribed from the original manuscripts at Smith College. London: Faber and Faber.

Pickering, A. D., Smillie, L. D., \& DeYoung, C. G. (2016). Neurotic individuals are not creative thinkers. Pers. Soc. Psychol. Rev, 2, 290-309.

Pompili, M. (June o1, 2008). Suicide on my mind, prevention on my agenda. Clinical Neuropsychiatry, 5, 3, 162-167.

Praz, M. (1991). The romantic agony. Oxford [Oxfordshire: Oxford University Press.

Rich, A. (2002). Arts of the possible: Essays and conversations. WW Norton \& Company.

Runco, M. A. (1998). Suicide and creativity: The case of Sylvia Plath. Death studies, 22(7), 637-654.

Segal, H. (1993). On the clinical usefulness of the concept of death instinct. International Journal of PsychoAnalysis, 74, 55-61. 
19 | Sylvia Plath, the Well-Bred Malaise, and its Confession in 'Daddy'

Sherwin, M. (2011)." Confessional" Writing and the Twentieth-century Literary Imagination. Palgrave Macmillan.

Shneidman, E. S. (1965). Some reflections on death and suicide. Psychiatry and Clinical Neurosciences, 19(4), 317-325.

Shulman, E. (1998). Vulnerability factors in Sylvia Plath's suicide. Death studies, 22(7), 597-613.

Silvia, P. J., \& Kaufman, J. C. (2010). Creativity and mental illness. In J. C. Kaufman \& R. J. Sternberg (Eds.), Cambridge handbook of creativity (pp. 381-394). New York, NY: Cambridge University Press.

Simonton, D. K. (2014). The mad-genius paradox: Can creative people be more mentally healthy but highly creative people more mentally ill?. Perspectives on Psychological Science, 9(5), 470-480.

Tamas, S. (2012). Biting the tongue that speaks you:(Re) writing survivor narratives. International Review of Qualitative Research, 4(4), 431-459.

Volkan, V. D., \& Zintl, E. (1993). Life after loss. New York: Charles Scribner's Sons.

Wagner-Martin, L. (2007). Sylvia Plath: The critical heritage. London: Routledge.

WENCKSTERN, A. A. L. S. (1998). Sylvia Plath: A protocol analysis of her last poems. Death studies, 22(7), 615-635.

Wood, N., \& Lodge, D. (2014). Modern Criticism and Theory. Florence: Taylor and Francis.

\begin{abstract}
About the author:
The author is an Associate Professor of English Literature in the Department of English Language and Literature, College of Arts and Sciences, Prince Sattam Bin Abdulaziz University, Saudi Arabia. Earlier he taught at the prestigious Lucknow Christian College in India. His research interests are Feminism, Gender Studies, Postcolonial Studies, Trauma Studies, and Literary Theory.
\end{abstract}

